Environment Conservation Journal 15(1 \& 2)153-159, 2014

ISSN 0972-3099 (Print) 2278-5124 (Online)

Abstracted and Indexed

\title{
Equilibrium isotherm studies for the sorption of Nickel ions onto coal fly ash
}

\author{
Ajay K. Agarwal ${ }^{1} \bowtie$, Mahendra S. Kadu ${ }^{1}$, Chandrashekhar P. Pandhurnekar ${ }^{2}$, Ishwardas \\ L. Muthreja ${ }^{3}$
}

Received:15.11.2013

Revised:19.02.2014

Accepted:02.04.2014

\begin{abstract}
The objective of the present study was to study equilibrium isotherm for the sorption of Nickel ions onto coal fly ash. In this study, BET adsorption isotherm was found to be best fitted among Langmuir, Freundlich, BET, Temkin and Harkins Jura adsorption isotherms using lest square fit method. The best fit adsorption isotherm is assessed by the linear coefficient of determination $\left(R^{2}\right)$ and non-linear Chi-square test. The theoretical value of $q_{e}$ calculated from the best fit linear equation of each adsorption isotherm and the experimental values of $q_{e}(0.08)$ are plotted against $C_{e}$, to compare the experimental and Theoretical value of $q_{\mathrm{e}}$.
\end{abstract}

Keywords: Adsorption, chi square test, fly Ash, isotherms, models, nickel

\section{Introduction}

Heavy metals in the wastewater have increased because of industrial and human activities. Erosion of surface deposits of metal minerals, agricultural runoff and acid rain contribute to heavy metals in wastewater naturally. Heavy metal containing wastewaters originate mainly from electroplating, metal finishing, metallurgical, chemical manufacturing, mining and battery manufacturing processes in considerable amounts (Krishnan and Anirudhan, 2002).Heavy metals are well-known toxic elements and their discharge into receiving water causes detrimental effects on human health and the environment (Reeve, 2007). Therefore, there is a need to treat heavy metal containing wastewaters before being discharged into the environment.Heavy metals are dangerous because they tend to bio-accumulate (Njoku and Ngene, 2012). The general body of literature on nickel toxicity indicates that, depending on the dose, the accidental inhalation of nickel carbonyl generally causes acute toxic effects in two stages, immediate and delayed. The immediate symptoms include headache, vertigo, nausea, vomiting, insomnia,

Author's Address

${ }^{1}$ Department of Civil Engineering, Shri Ramdeobaba College of Engineering and Management, Nagpur, Maharashtra, India

${ }^{2}$ Department of Chemistry, Shri Ramdeobaba College of

Engineering and Management, Nagpur, Maharashtra, India.

${ }^{3}$ Department of Mining Engineering, Visvesvaraya National Institute of Technology, Nagpur, Maharashtra, India

Email: agarwal_rkn@rediffmail.com irritability, which usually last a few hours, followed by an asymptomatic interval of $12 \mathrm{~h}$ to 5 days.

The delayed symptoms appear-tightness of the chest, nonproductive cough, dyspnoea, cyanosis, tachycardia, palpitations, sweating, visual disturbances, vertigo, weakness, and lassitude (AlAsheh and Duvnjak, 1997).

Various methods have been reported for the removal of heavy metals from industrial effluents, such as ion exchange, evaporation, chemical reduction, precipitation, electrolysis, electroplating, ion flotation and carbon adsorption etc. (Gupta and Torres, 1998).However most of these methods suffer from some drawbacks such as high capital and operational cost or the treatment and disposal of the residual metal sludge (Takaoka et al., 2002). Adsorption is the other method which is very cost effecting and hardly involves any cost for its processing (Fattahpour et al., 1996).

Waste material from another industry, which has lost its economic or further processing values, can be used as an adsorbent. In this study, untreated coal fly ash has been used and five different adsorption isotherm models such as Langmuir, Freundlich, BET, Temkin and Harkins Jura were examined for their ability to model the equilibrium sorption data. Chi square test a non-linear error function was examined for each isotherm parameters. 


\section{Material and methods}

\section{Fly Ash}

Sample of the raw coal fly ash was collected from Unit 7 of Electrostatic Precipitator (ESP) hopper number 5 of a coal-burning thermal power plant situated at Koradi, Nagpur District, Maharashtra, India, it was used without pretreatment. The fly ash powder was dried in the electric oven at $120{ }^{\circ} \mathrm{C}$ for at least 24 hours. The chemical composition of fly ash was found to be: $\mathrm{SiO}_{2}(62.6 \%), \mathrm{Al}_{2} \mathrm{O}_{3}$ (24.41\%), $\mathrm{Fe}_{2} \mathrm{O}_{3}$ (4.04), $\mathrm{TiO}_{2}(0.69 \%), \mathrm{CaO}(0.35)$, $\mathrm{MgO}(0.54), \mathrm{Na}_{2} \mathrm{O}(0.27 \%), \mathrm{K}_{2} \mathrm{O}(0.21 \%), \mathrm{SO}_{3}$ $(0.84 \%), \mathrm{P}_{2} \mathrm{O}_{5}(0.037 \%), \mathrm{MnO}(0.28 \%)$ and Loss on ignition $(1.27 \%)$. According to American Society for Testing and Materials (ASTM) C-618 this fly ash can be classified as class $\mathrm{F}$ for having a less than $5 \% \mathrm{SO}_{3}$ content and loss on ignition less than $6 \%$ with a greater than $70 \%$ content of three components- $\mathrm{SiO}_{2}, \mathrm{Al}_{2} \mathrm{O}_{3}$ and $\mathrm{Fe}_{2} \mathrm{O}_{3}$ (Pourkhorshidi et al. 2010). The particle size distribution was done using standard method by passing the fly ash over the standard size molecular sieves. It was found that $91.12 \%$ fly ash particles have size below $75 \mu \mathrm{m}$. Scanning electron microscopy (SEM) analysis of fly ash was carried out using scanning electron microscope (Model Philips SEM 515) between 25 $\mathrm{kV}$ to $30 \mathrm{kV}$ to study the surface texture and morphology of received fly ash sample. To determine the major mineral components of fly ash, X-ray diffraction spectra (XRD) were recorded over the $2 \theta$ range of 0 to $65^{\circ}$ using Philips X-PertProXRD diffractometer equipment with a $\mathrm{CuK} \alpha$ radiation source. The zeta potential of fly ash sample at different $\mathrm{pH}$ was determined by a Zetameter System 4.0 (Zetameter Inc. Staunton, VA 24402, USA). The surface area of the fly ash used has been determined by using Brunauer, Emmett and Teller (BET) Theory (Bruanuer et al, 1938). The BET method is based on adsorption of gas on an adsorbent surface. The surface area was determined on Micromeritics ASAP 2020 V3.04 H, surface area analyzer using liquid nitrogen gas.

\section{Preparation of $\mathrm{Ni}^{2+}$ ions standard solution}

The analytical reagent grade nickel sulphate hexahydrate (Merck, India, mass fraction purity $99.9 \%$ ) was used for the batch adsorption study. The stock solution of $\mathrm{Ni}^{2+}(500 \mathrm{mg} / \mathrm{l})$ was prepared by dissolving $4.4783 \mathrm{~g} \mathrm{NiSO}_{4} \times 6 \mathrm{H}_{2} \mathrm{O}$ in 2 liters freshly prepared double distilled water. To carry out various studies, this stock solution of $500 \mathrm{mg} / 1$ was diluted by adding the double distilled water, as per the requirement of the study.

\section{Experimental}

The aqueous solutions containing $20 \mathrm{mg} / 1,40 \mathrm{mg} / \mathrm{l}$, $60 \mathrm{mg} / 1,100 \mathrm{mg} / 1$ and $200 \mathrm{mg} / 1 \mathrm{Ni}^{+2}$, were prepared from the stock solution $(500 \mathrm{mg} / \mathrm{l})$. In the $100 \mathrm{ml}$ of these samples, $10 \mathrm{~g}$ fly ash was added. These samples were stirred constantly at $150 \mathrm{rpm}$ for 3 hours to attain the equilibrium time. The adsorbent were separated from the solution by centrifuge at a speed of $3000 \mathrm{rpm}$ for 5 minutes and the supernant $\mathrm{Ni}^{+2}$ solution were used to measure atomic adsorption spectra. The $\mathrm{Ni}^{+2}$ adsorption isotherm in aqueous solutions were obtained from the study. Atomic absorption spectra were recorded on an atomic absorption spectrophotometer (Model GBC 932 AA).

\section{Adsorption isotherms}

To optimize the design of a sorption system for the sorption of $\mathrm{Ni}^{+2}$ ions from the aqueous solution, it is important to establish the most appropriate correlation for the equilibrium curves. The results obtained from batch adsorption experiments in the present work were fitted to Langmuir, Freundlich, BET, Temkin and Harkins Jura adsorption isotherms using lest square fit method. The standard model of Langmuir equation (Langmuir, 1918) used is represented below:

$$
\frac{\mathrm{C}_{\mathrm{e}}}{\mathrm{q}_{\mathrm{e}}}=\frac{1}{\mathrm{q}_{\mathrm{m}}} \mathrm{C}_{\mathrm{e}}+\frac{1}{\mathrm{~K}_{\mathrm{a}} \cdot \mathrm{q}_{\mathrm{m}}}
$$

where, $\mathrm{C}_{\mathrm{e}}$ is equilibrium concentration of $\mathrm{Ni}^{+2}$ ions (mg. $\left.l^{-1}\right), \mathrm{q}_{\mathrm{e}}$ is solid phase concentration of $\mathrm{Ni}^{+2}$ ions $\left(m g \cdot g^{-1}\right), q_{m}\left(m g \cdot g^{-1}\right)$, and $K_{a}\left(1 . \mathrm{mg}^{-1}\right)$ are empirical constants, can be evaluated from the slope and intercept of the linear plot of $\mathrm{C}_{\mathrm{e}} / \mathrm{q}_{\mathrm{e}}$ against $\mathrm{C}_{\mathrm{e}}$. The standard model of Freundlich Equation (Freundlich, 1906) used is represented below:

$$
\ln \mathrm{q}_{\mathrm{e}}=\ln \mathrm{K}_{\mathrm{f}}+\frac{1}{\mathrm{n}} \ln \mathrm{C}_{\mathrm{e}}
$$

where, $\mathrm{K}_{\mathrm{f}}$ is the Freundlich characteristic constant $\left[\left(\mathrm{mg} \cdot \mathrm{g}^{-1}\right)\left(1 \cdot \mathrm{g}^{-1}\right)^{1 / \mathrm{n}}\right]$ and $1 / \mathrm{n}$ is the heterogeneity factor of sorption, obtained from intercept and slope of $\ln$ $\mathrm{q}_{\mathrm{e}}$ versus $\ln \mathrm{C}_{\mathrm{e}}$ linear plot respectively. 
The BET isotherm model (Bruanuer et al, 1938) in the linear form as used is represented as

$$
\frac{\mathrm{C}_{\mathrm{e}}}{\mathrm{q}_{\mathrm{e}}\left(\mathrm{C}_{\mathrm{S}}-\mathrm{C}_{\mathrm{e}}\right)}=\frac{1}{\mathrm{q}_{\mathrm{s}} \mathrm{C}_{\mathrm{BET}}}+\frac{\left(\mathrm{C}_{\mathrm{BET}}-1\right)}{\mathrm{q}_{\mathrm{s}} \mathrm{C}_{\mathrm{BET}}}\left(\frac{\mathrm{C}_{\mathrm{e}}}{\mathrm{C}_{\mathrm{S}}}\right)
$$

Where

$\mathrm{C}_{\mathrm{e}}=$ equilibrium concentration $(\mathrm{mg} / \mathrm{l})$

$\mathrm{C}_{\mathrm{s}}=$ adsorbate monolayer saturation concentration (mg/l)

$\mathrm{C}_{\mathrm{BET}}=\mathrm{BET}$ adsorption isotherm relating to the energy of surface interaction $(1 / \mathrm{mg})$

The standard model of Temkin isotherm Equation (Temkin and Pyzhev, 1940) used is represented below:

$\mathrm{q}_{\mathrm{e}}=\mathrm{B} \ln \mathrm{A}_{\mathrm{T}}+\mathrm{B} \ln \mathrm{C}_{\mathrm{e}}$

$\mathrm{A}_{\mathrm{T}}=$ Temkin isotherm equilibrium binding constant

$(\mathrm{L} / \mathrm{g})$

$\mathrm{B}=$ Constant related to heat of sorption $(\mathrm{J} / \mathrm{mol})$

The Harkins-Jura isotherm (Harkin and Jura, 1944) used in the linear form can be represented as follows:

$\frac{1}{\mathrm{q}_{\mathrm{e}}^{2}}=\frac{\mathrm{B}}{\mathrm{A}}-\frac{1}{\mathrm{~A}} \ln \mathrm{C}_{\mathrm{e}}$

Where $\mathrm{A}$ and $\mathrm{B}$ are isotherm parameter and constant.

The amount of metallic ion adsorbed by the fly ash in $\mathrm{mg} / \mathrm{g}$ was calculated using equation 6 (Devarly et al. 2012):

$$
q_{e}=\frac{\left(\mathrm{C}_{0}-\mathrm{C}_{\mathrm{e}}\right) \cdot \mathrm{V}}{\mathrm{w}}
$$

Where, $C_{0}$ and $\mathrm{C}_{\mathrm{e}}$ are the initial and final concentration expressed in $\mathrm{mg} / \mathrm{l}, \mathrm{V}$ is the volume of aqueous solution in litres, and $\mathrm{w}(\mathrm{g})$ is the mass of the adsorbent added in the solution.

\section{Chi-square test}

Chi-square is a statistical test commonly used to compare observed data with data we would expect to obtain according to a specific hypothesis (Bagdonavicius and Nikulin, 2011). The Chi-square test statistic is basically the sum of the squares of the differences between the experimental data and the data obtained by calculating from models, with each squared difference divided by the corresponding data calculated using the models (Chatterjee et al. 2009). In this study, the Chisquare test were performed for all the isotherm models using the mathematical expression

$$
\chi^{2}=\sum \frac{\left(\mathrm{q}_{\mathrm{e}, \text { calc }}-\mathrm{q}_{\mathrm{e}}\right)^{2}}{\mathrm{q}_{\mathrm{e}, \text { calc }}}
$$

where

$\mathrm{q}_{\mathrm{e}}$, calc is the equilibrium (theoretical) capacity obtained by calculated from model $(\mathrm{mg} / \mathrm{g})$ and $\mathrm{q}_{\mathrm{e}}$ is the equilibrium capacity $(\mathrm{mg} / \mathrm{g})$ from the experimental data.

\section{Results and discussion}

Figure 1 shows the SEM micrograph of a coal fly ash sample at 5000x magnification. It is seen that, fly ash particles are mostly spherical in shape, whereas small amount of irregular shaped particles are also present.

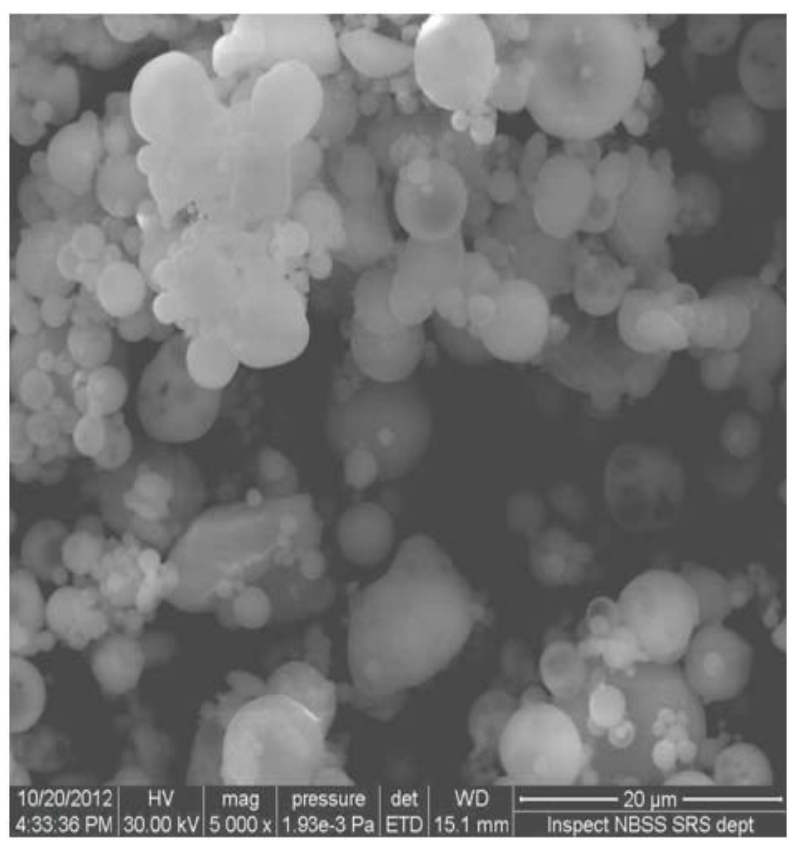

Figure 1 SEM image of fly ash sample (magnification: 5000x)

It was found that zeta potential increases continuously with $\mathrm{pH}$ of the solution and it was observed that the values of zeta potential were 
varying from $-13.2 \mathrm{mV}$ to $-37.6 \mathrm{mV}$ for the $\mathrm{pH}$ range of 2.0 to 9.0 .

The values of BET Surface Area of fly ash sample was found to be $10.5777 \pm 0.1429 \mathrm{~m}^{2} / \mathrm{g}$.

The Figure 2 shows the X-ray diffraction pattern for the fly ash sample. The observed peaks were assigned to their respective components. It can be seen from the diffractogram of fly ash sample that components are mainly present in their oxide form.

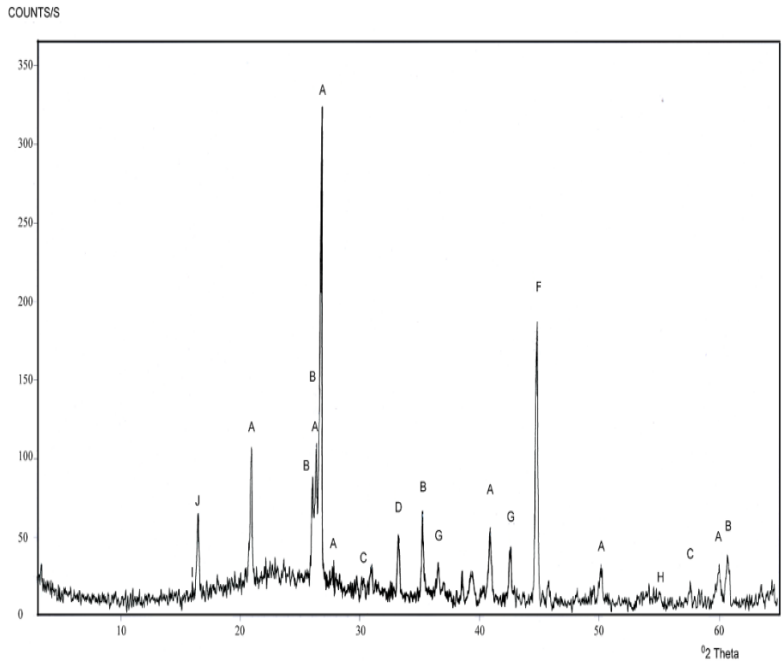

Figure 2 XRD spectra of fly ash sample.

Where,

A - quartz , silicon dioxide $\left(\mathrm{SiO}_{2}\right)$

$\mathrm{B}$ - mulite, aluminum silicon oxide $\left(3 \mathrm{Al}_{2} \mathrm{O}_{3} \times 2 \mathrm{SiO}_{2}\right)$

$\mathrm{C}$ - magnetite $\left(\mathrm{Fe}_{3} \mathrm{O}_{4}\right)$

$\mathrm{D}$ - hematite $\left(\mathrm{Fe}_{2} \mathrm{O}_{3}\right)$

$\mathrm{E}$ - leucite, potassium aluminumsilicate $\mathrm{K}\left(\mathrm{AlSi}_{2} \mathrm{O}_{6}\right)$

$\mathrm{F}$ - magnesium silicate $\left(\mathrm{Mg}_{2} \mathrm{SiO}_{4}\right)$

$\mathrm{G}$ - silicon oxide $\left(\mathrm{SiO}_{2}\right)$

$\mathrm{H}$ - rutile, $\left(\mathrm{TiO}_{2}\right)$

$\mathrm{I}$ - calcium aluminum sulphite hydrate $\left(\mathrm{Ca}_{6} \mathrm{Al}_{2} \mathrm{O}_{6}\left(\mathrm{SO}_{3}\right) \times 32 \mathrm{H}_{2} \mathrm{O}\right)$

The results obtained from batch adsorption experiments in the present work were fitted to Langmuir, Freundlich, BET, Temkin and Harkins Jura adsorption isotherms using lest square fit method. The Langmuir and Freundlich isotherm were obtained by plotting $\mathrm{C}_{\mathrm{e}} / \mathrm{q}_{\mathrm{e}}$ against $\mathrm{C}_{\mathrm{e}}$ and $\ln$ $\mathrm{q}_{\mathrm{e}}$ versus $\ln \mathrm{C}_{\mathrm{e}}$ as shown in Figure 3 and Figure 4 respectively. BET, Temkin and Harkins Jura adsorption isotherms were obtained by plotting $\mathrm{C}_{\mathrm{e}} / \mathrm{q}_{\mathrm{e}}\left(\mathrm{C}_{\mathrm{s}}-\mathrm{C}_{\mathrm{e}}\right)$ against $\mathrm{C}_{\mathrm{e}} / \mathrm{C}_{\mathrm{s}}, \ln \mathrm{C}_{\mathrm{e}}$ verses $\mathrm{q}_{\mathrm{e}}$ and $1 / \mathrm{q}_{\mathrm{e}}{ }^{2}$ against $\ln \mathrm{C}_{\mathrm{e}}$ as shown in Figure 5, Figure 6 and Figure 7 respectively. To compare the experimental values and calculated value (Theoretical value) of $\mathrm{q}_{\mathrm{e}}$ calculated from the best fit linear equation of each adsorption isotherm a graph as shown in Figure 8 is also plotted y between $\mathrm{C}_{\mathrm{e}}$ and all theoretical as well as experimental value of $\mathrm{q}_{\mathrm{e}}$.

The various adsorption isotherm constants determined from the slope and intercept from the respective plot are tabulated in the Table 1. The value of Chi square for each adsorption isotherm is also calculated and tabulated in the same table. The best fit among the isotherm models is assessed by the linear coefficient of determination $\left(\mathrm{R}^{2}\right)$ and nonlinear Chi-square test.

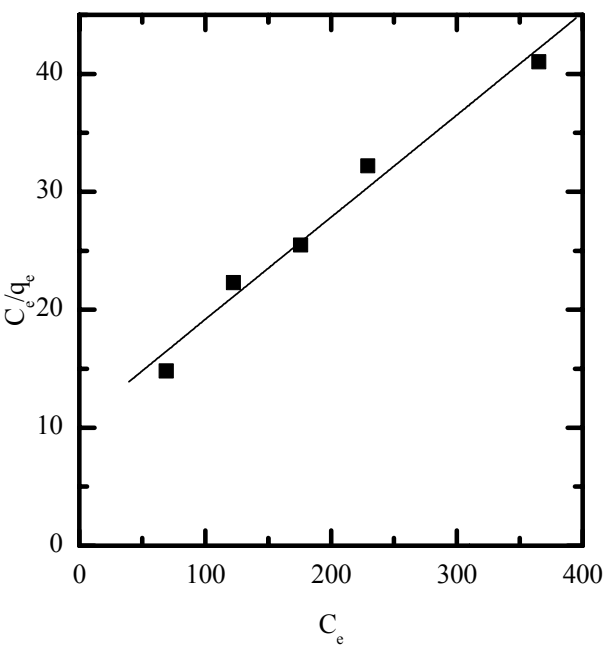

Figure 3 Langmuir adsorption isotherm of $\mathrm{Ni}^{+2}$ ions from aqueous solution using fly ash adsorbent

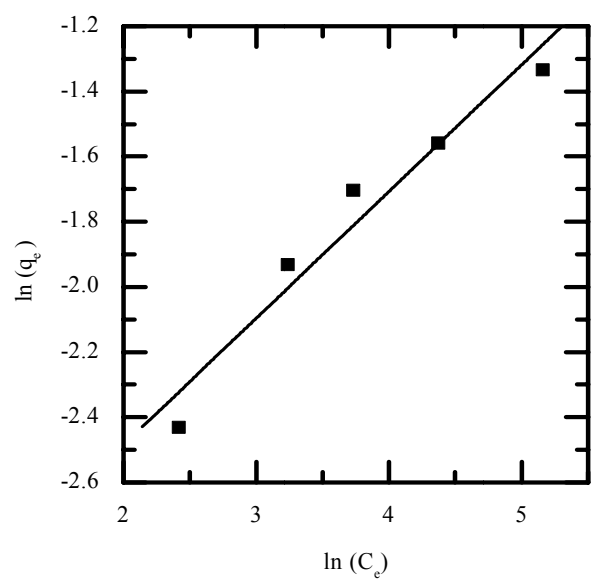

Figure 4 Freundlich adsorption isotherm of $\mathrm{Ni}^{+2}$ ions from aqueous solution using fly ash adsorbent 


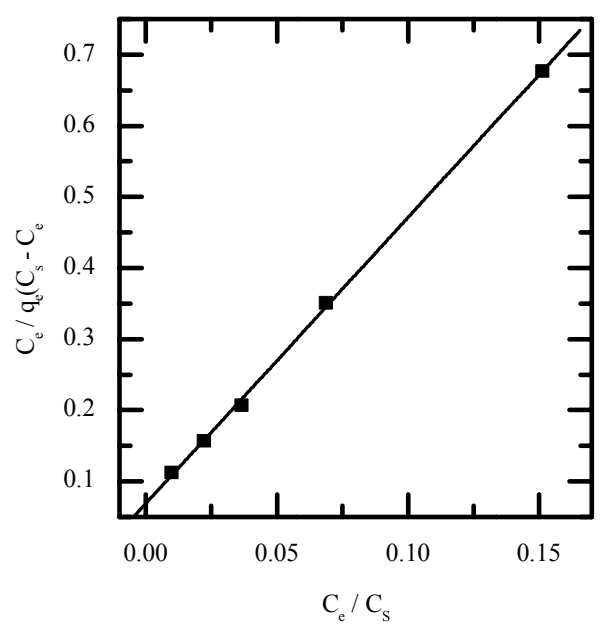

Figure 5 BET adsorption isotherm of $\mathrm{Ni}^{+2}$ ions from aqueous solution using fly ash adsorbent

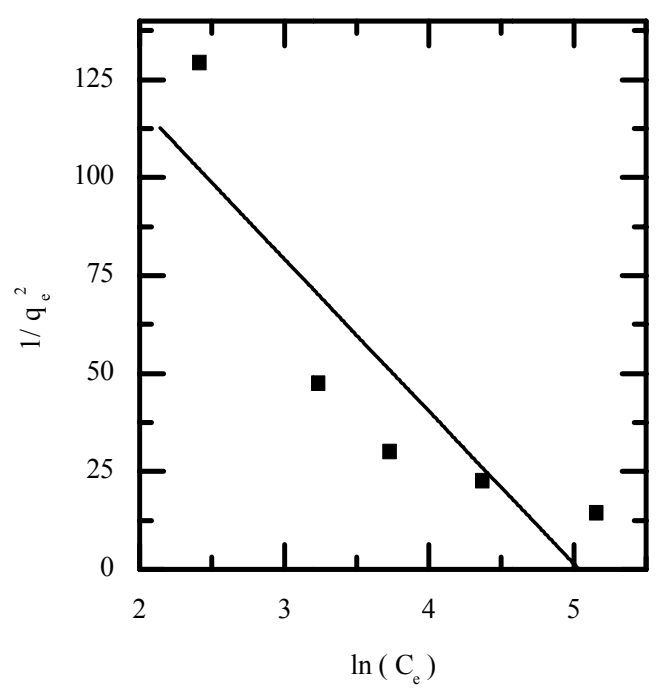

Figure 7 Harkins Jura adsorption isotherm of $\mathrm{Ni}^{+2}$ ions

It can be seen from the Table 1 that among the linear form of all five adsorption isotherm models used i. e. Langmuir, Freundlich, BET, Temkin and Harkins Jura Model, the values of regression Coefficient, $\mathrm{R}^{2}$ are better than 0.99 except in the case of Freundlich and Harkins Jura adsorption isotherm. The best adsorption isotherm fitting was

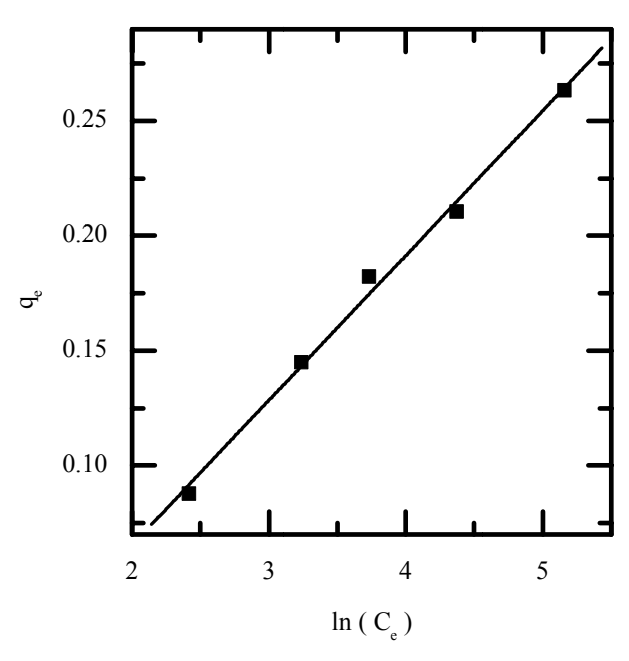

Figure 6 Temkin adsorption isotherm of $\mathrm{Ni}^{+2}$ ions from aqueous solution using fly ash adsorbent

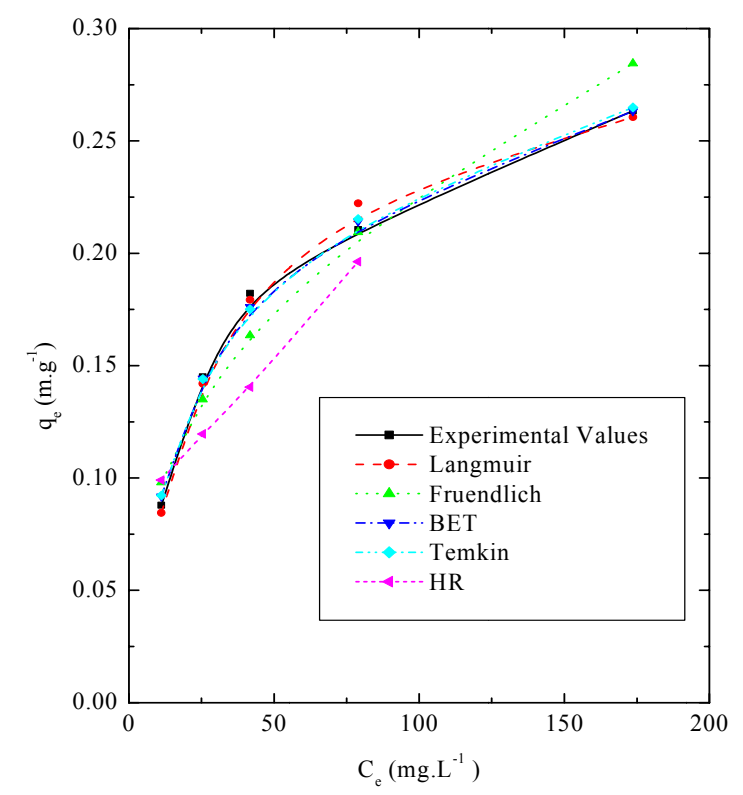

Figure 8 Comparison of experimental and theoretical value of $q_{e}$ for different isotherms.

found when BET Adsorption model has been used. In the present study, non-linear fitting of these models was also tested by plotting values of experimental data of $\mathrm{q}_{\mathrm{e}}$ against calculated $\mathrm{q}_{\mathrm{e}}$ by using the entire model and were plotted against experimental values of $\mathrm{C}_{\mathrm{e}}$ which has been shown in Figure 8. 
Agarwal et al.

Table 1 Langmuir, Freundlich, BET, Temkin and Harkins Jura adsorption isotherm constants for $\mathrm{Ni}^{+2}$

\begin{tabular}{|c|c|c|c|c|}
\hline \multicolumn{5}{|c|}{ Langmuir Adsorption Isotherm Constants } \\
\hline $\mathrm{q}_{\mathrm{m}}\left(\mathrm{mg} \cdot \mathrm{g}^{-1}\right)$ & & $\mathrm{k}_{\mathrm{a}}\left(1 . \mathrm{mg}^{-1}\right)$ & $\mathrm{R}^{2}$ & $\sum \chi^{2}$ \\
\hline 0.304321 & & 0.034319 & 0.997 & 0.00089964 \\
\hline \multicolumn{5}{|c|}{ Freundlich Adsorption Isotherm Constants } \\
\hline $\mathrm{n}$ & & $\mathrm{K}_{\mathrm{f}}\left(\mathrm{mg} \cdot \mathrm{g}^{-1}\right)$ & $\mathrm{R}^{2}$ & $\sum \chi^{2}$ \\
\hline 2.570694 & & 0.038273 & 0.950 & 0.0055095765 \\
\hline \multicolumn{5}{|c|}{ BET Adsorption Isotherm Constants } \\
\hline $\mathrm{q}_{\mathrm{s}}$ & $\mathrm{C}_{\mathrm{S}}$ & $\mathrm{C}_{\mathrm{BET}}$ & $\mathrm{R}^{2}$ & $\sum \chi^{2}$ \\
\hline 0.244379277 & 1148.23 & 60.17647059 & 0.999 & 0.00044943 \\
\hline \multicolumn{5}{|c|}{ Temkin Adsorption Isotherm Constants } \\
\hline $\mathrm{A}_{\mathrm{T}}$ & & $\mathrm{B}$ & $\mathrm{R}^{2}$ & $\sum \chi^{2}$ \\
\hline 0.385821 & & 0.063 & 0.994 & 0.000606503 \\
\hline \multicolumn{5}{|c|}{ Harkins Jura Adsorption Isotherm Constants } \\
\hline A & & $\mathrm{B}$ & $\mathrm{R}^{2}$ & $\sum \chi^{2}$ \\
\hline 0.025707 & & 5.03599 & 0.764 & 0.020103701 \\
\hline
\end{tabular}

It can be observed from the figure that BET adsorption isotherm and Temkin adsorption isotherm models produces closer values of $\mathrm{q}_{\mathrm{e}}$ in comparison to the experimental values, whereas Harkins Jura Model does not fit well and show maximum deviation in the plot. This can be clearly understood by comparing the values of $\chi^{2}$ of these entire model (Table 1) wherein $\chi^{2}$ varies in the following order.

BET $<$ Temkin $<$ Langmuir $<$ Freundlich $<$ Harkins Jura

Thus, in both, linear and non-linear form, BET adsorption isotherm model found to be more accurate model.

\section{Conclusion}

Among the linear form of all five adsorption isotherm models used i.e. Langmuir, Freundlich, BET, Temkin and Harkins Jura Model, the values of regression Coefficient, $\mathrm{R}^{2}$ are better than 0.99 except in the case of Freundlich and Harkins Jura adsorption isotherm. The best adsorption isotherm fitting was found when BET Adsorption model has been used. This can be clearly understood by comparing the values of $\chi^{2}$ of these entire model wherein $\chi^{2}$ varies in the following order BET $<$ Temkin $<$ Langmuir $<$ Freundlich $<$ Harkins Jura. Thus, in both, linear and non-linear form, BET adsorption isotherm model found to be more accurate model.

\section{References}

Al-Asheh, S. and Duvnjak, Z. 1997. Sorption of cadmium and other heavy metals by pine bark, Advance Environment Research, 1: 194.

Bagdonavicius, V. and Nikulin, M.S. 2011. Chi-square goodness-of-fit test for right censored data, The International Journal of Applied Mathematics and Statistics, 30-50.

Brunauer, S., Emmett, P. H. and Teller, E. 1938. Adsorption of gases in multi molecular layers, Journal of American Chemical Societ, 60: 309-319.

Chatterjee S., Dae S. L., Lee, M. W. and Seung H. W. 2009. Enhanced adsorption of congo red from aqueous solutions by chitosan hydrogel beads impregnated with cetyl trimethyl ammonium bromide, Bioresource Technoology, 100: 2803-2809 
Devarly, P., Liu, J. C., Suryadi, I. and Wang, M. J. 2012. Adsorption of Tetramethylammonium Hydroxide on Activated Carbon, Journal of Environmental Engineering -ASCE 138:232-238.

Fattahpour, S. I., Igsell, P., Ringqvist, L. and Lindström, E. B. 1996. Comparison of metal adsorption properties and determination of metal adsorption capacities of different peat samples, Resource and Environmental Bio technology, 1: 111-128.

Freundlich, H. 1906. Adsorption in solution, Physical Chemistry, 57: 384-410.

Gupta, G. and Torres, N. 1998. Use of fly ash in reducing toxicity of and heavy metals in wastewater effluent, Journal of Hazardous Materials, 57(1-3): 243-248.

Harkins, W. D. and Jura, G. 1944. A vapor adsorption Method for the determination of the Area of a Solid without the Assumption of Molecular Area, and the Areas Occupied by Nitrogen and Other Molecules on the Surface of a Solid, Journal of American Chemical Society, 66: 1366-1377.

Krishnan, K. A. and Anirudhan, T. S. 2002. Removal of mercury (II) from aqueous solutions and chlor-alkali industry effluent by steam activated and sulphurised activated carbons prepared from bagasse pith: Kinetics and equilibrium studies, Journal of Hazardous Materials, B 92: 161-183.
Langmuir, I. 1918. Adsorption of gases on plane surfaces of glass, mica and platinum, Journal of American Chemical Society, 40: 1361-1403.

Njoku, C. and Ngene, P. N. 2012. Content and Distribution of Heavy Metals in an Abandoned Mechanic and NonMechanic Sites in Abakaliki, Southeastern Nigeria, Greener Journal of Physical Science, 2(1): 016-019.

Pourkhorshidi, A. R., Najimi, M., Parhizkar, T., Jafarpour, F. and Hillemeier, B. 2010. Applicability of the standard specifications of ASTM C618 for evaluation of natural pozzolans, Cement Concrete Composition, 32(10): 794800

Reeve, D. J. 2007. Environmental improvements in the metal finishing industry, Journal of Cleaner Production, 15(89): 756-763.

Takaoka, M., Kawai, T., Takeda, N. and Oshita, K. 2002. Recovery of Heavy Metals in Fly ash from Ash Melting Furnace by Solvent Extraction, Proceedings of Environmental Engineering Research, 39: 403-412.

Tempkin, M. I. and Pyzhev, V. 1940. Kinetics of ammonia synthesis on promoted iron catalyst, Acta Physica Chimica., USSR 12: 327-356. 